\title{
Pengaruh Kepercayaan Merek, Citra Merek, Dan Kepuasan Merek Terhadap Loyalitas Merek Serta Keinginan Pembelian Ulang Koran Jawa Pos Pada Masyarakat Surabaya
}

\author{
Hendri Rahman Susetyo ${ }^{1}$ \\ hendri.rahman@gmail.com \\ Sekolah Tinggi Ilmu Ekonomi (STIE) Perbanas Surabay \\ Mochamad Rizal Yulianto ${ }^{2}$ \\ rizaldo@umsida.ac.id \\ Sekolah Tinggi Ilmu Ekonomi (STIE) Perbanas Surabaya
}

\begin{abstract}
Abstrak
Tujuan penelitian ini adalah menguji pengaruh kepercayaan merek, citra merek, dan kepuasan merek terhadap loyalitas merek serta keinginan pembelian ulang koran Jawa Pos di kota Surabaya. Berdasarkan tinjauan literatur, hipotesis penelitian ini menyatakan bahwa kepercayaan merek, citra merek, dan kepuasan merek berpengaruh terhadap loyalitas merek, selain itu hasil tinjauan literatur menunjukkan bahwa loyalitas merek berpengaruh terhadap keinginan pembelian ulang. Data penelitian ini dikumpulkan dengan menggunakan kuesioner dari responden yang terdiri dari 210 pelanggan koran Jawa Pos di kota Surabaya. Teknik pengujian hipotesis dilakukan dengan menggunakan analisis structure equation model (SEM) dengan aplikasi statistik SmartPLS. Hasil penelitian ini menunjukkan bahwa kepercayaan merek, citra merek, dan kepuasan merek berpengaruh positif terhadap loyalitas merek, dan juga loyalitas merek berpengaruh positif terhadap keinginan pembelian ulang. Secara khusus, penelitian ini menunjukkan bahwa pelanggan yang loyal akan terus melakukan pembelian berulang.
\end{abstract}

Kata-kata kunci: citra, kepercayaan, kepuasan, loyalitas, merek, keinginan pembelian ulang

\section{Pendahuluan}

Kehidupan modern saat ini secara tidak langsung terbentuk karena adanya teknologi informasi dan komunikasi yang baru. Sebagai pendorong utama dari transformasi di era modern ini, digitalisasi dan jaringan interkoneksi telah menciptakan berbagai layanan seperti jaringan selular dan internet (Kilian et al. 2012). Dalam beberapa tahun terakhir, internet telah menjadi sumber utama dalam pencarian informasi dan berita yang mengancam masa depan surat kabar di seluruh dunia. Selain itu, distribusi surat kabar juga dipengaruhi oleh ketersediaan dari berita online, website, dan sosial media yang pada akhirnya mempengaruhi jumlah penjualan surat kabar (Alotaibi 2015).

Di beberapa negara maju, pembaca melalui platform digital telah melampaui jumlah pembaca pada media cetak. Analisa World Press Trends memperkirakan bahwa setidaknya 40 persen dari pengguna internet global menggunakan internet untuk membaca surat kabar online. (Henriksson, 2016). Survei dari World Association of Newspapers and News Publishers (WAN-IFRA) yang dilakukan pada tahun 2013 menunjukkan adanya variasi dalam distribusi surat kabar. Survei tersebut membandingkan distribusi koran pada tahun 2012 dan selama lima tahun terakhir. Hasil survei menunjukkan bahwa terjadi penurunan global dalam distribusi surat kabar selama beberapa tahun lalu yaitu sebesar 0,9 persen, sementara 
penurunan dalam lima tahun terakhir mencapai 2,2 persen (Kilman 2013). Sedangkan survei lanjutan yang dilakukan oleh WAN-IFRA pada tahun 2015, menemukan bahwa total pendapatan koran global turun 1,2 persen dari tahun sebelumnya dan turun 4,3 persen selama lima tahun terakhir (Henriksson 2016).

Grafik statistik menunjukkan hal yang memilukan dalam perkembangan bisnis surat kabar di masa sekarang. Masalah yang dihadapi adalah fakta bahwa penurunan pendapatan cetak untuk iklan pada surat kabar yang mulai melambat atau bahkan telah terjun bebas selama bertahun-tahun (Gigaom 2014). Penelitian yang dilakukan oleh Roy Morgan Research tahun 2016 pada 22 kota yang ada di Indonesia, menghasilkan bahwa penetrasi internet 54 persen dan koran 38 persen. Sedangkan pada tingkat provinsi Jawa Timur, penetrasi internet hanya 43 persen dan koran 39 persen (Roymorgan 2016).

Grafik statistik menunjukkan hal yang memilukan dalam perkembangan bisnis surat kabar di masa sekarang. Masalah yang dihadapi adalah fakta bahwa penurunan pendapatan cetak untuk iklan pada surat kabar yang mulai melambat atau bahkan telah terjun bebas selama bertahun-tahun (Gigaom 2014). Dari hasil survei terungkap, bahwa market share koran memang tergerus cukup dalam, sehingga secara total konsumennya kini tinggal 39,3 persen. Selain itu Indikasi kuat akan semakin merosotnya minat konsumen/masyarakat terhadap koran juga dapat dilihat dari semakin rendahnya pelanggan koran, yaitu tinggal 15,1 persen, atau turun sekitar 2 persen dibanding tahun lalu yang sebesar 17,7 persen (Siswanto, 2017).

Banyak dilema yang dirasakan oleh penerbit koran pada saat ini, seperti penuaan pembaca, menurunnya pendapatan dan pembaca yang mulai hilang. Selain dilema tersebut alasan lain yang menjadi masalah dan ancaman dalam bisnis ini adalah teknologi internet yang menguasai sebagian besar populasi muda. Tantangan yang dihadapi oleh industri surat kabar memaksa mereka untuk memikirkan kembali pemikiran mengenai praktik bisnis, presentasi dan bagaimana menjangkau target pelanggan (Frooghi et al. 2015).

Ketika konsumen surat kabar cetak beralih untuk membaca koran secara online, surat kabar mengalami tekanan yang besar dan mulai berfikir untuk menghasilkan uang dari portal online mereka sendiri. Perjuangan industri surat kabar masih sangat berat untuk tetap mendapatkan keuntungan ketika disruptive technologies mengganggu mereka dan hal ini merupakan tradisi panjang industri media mapan yang tidak siap untuk diadaptasi, dan disesuaikan dengan, teknologi baru (Kueng dan Picard 2010). Liu et al. (2011) menyatakan bahwa kepercayaan merek merupakan faktor mediator penting yang mempengaruhi perilaku konsumen sebelum dan sesudah pembelian produk, hal tersebut akan menghasilkan loyalitas jangka panjang dan memperkuat hubungan antara kedua belah pihak.

Berbasis di Surabaya, Jawa Pos merupakan salah satu koran dengan jaringan terbesar yang ada di Indonesia yang mempunyai 167 surat kabar, 21 majalah/tabloid, 23 stasiun TV lokal, dan 20 lebih situs berita. Jawa Pos sendiri mengklaim sebagai "Harian Nasional yang Terbit dari Surabaya" karena pada Pada 1 Juli 1949 Jawa Pos lahir nama Djawa Post di kota Surabaya, Jawa Timur. Berdasarkan survey dari Roy Morgan Single Source Indonesia pada tahun 2016 didapatkan hasil bahwa koran Jawa Pos sebagai salah satu media cetak yang paling mendominasi di kota Surabaya, dimana pembacanya mencapai 1.622 .000 orang. Hal ini tentu saja sangat mengejutkan, ditengah gempuran media online yang semakin menjamur pada saat ini.

Koran yang lahir di Surabaya ini tetap mendominasi walaupun koran dan media cetak lainnya mulai menyerah satu persatu ketika bersaing di bisnis ini. Citra koran Jawa Pos yang telah mengakar kuat pada masyakarat Surabaya ini memberi angin positif untuk Jawa Pos sehingga terus bertahan dan meninggalkan pesaingnya. Tetapi apakah citra merek koran Jawa Pos yang sudah dikenal baik oleh masyarakat Surabaya dapat membuat suatu kepuasan dalam diri masyarakat ketika menjadi pembaca koran Jawa Pos? Begitu pula bagaimana dengan 
keinginan pembelian ulang dari pembaca Jawa Pos ketika pencarian berita kini semakin mudah dengan adanya internet? Akankah koran Jawa Pos tetap diterima masyarakat Surabaya atau ditinggalkan seperti koran yang telah dahulu tutup usia karena tidak kuat menghadapi persaingan di era digital?

Media online yang awalnya sebagai alternatif dari media tradisional, telah menjadi media yang tidak tergantikan dan mulai mengubah pola komunikasi kita pada saat ini. Oleh karena itu kepercayaan dan citra merek dari koran Jawa Pos Koran dipertaruhkan dalam menghadapi persaingan global dalam bisnis ini ditengah hilangnya media cetak dari tahun ke tahun. Berbagai hal dilakukan perusahaan untuk tetap mengembangkan perusahaan dan menciptakan masa depan yang lebih baik, salah satunya adalah dengan cara menciptakan loyalitas pelanggan. Berdasarkan hasil penelitian dari Nielsen Indonesia pada tahun 2014 dan Roy Morgan Research pada tahun 2016 seperti yang telah dijabarkan diatas, peneliti ingin mengetahui apakah ada pengaruh antara kepercayaan merek, citra merek, kepuasan merek terhadap loyalitas merek serta keinginan pembelian ulang koran Jawa Pos pada masyarakat Surabaya di tengah berkembangnya internet saat ini.

Tabel 1

Profil Responden

\begin{tabular}{|c|c|c|c|}
\hline Profil Responden & Kategori & Frekuensi & Persentase \\
\hline \multirow[t]{3}{*}{ Jenis Kelamin } & Pria & 115 & 54.8 \\
\hline & Wanita & 95 & 45.2 \\
\hline & Total & 210 & 100 \\
\hline \multirow[t]{7}{*}{ Usia } & $<20$ tahun & 6 & 2.9 \\
\hline & 21-30 tahun & 46 & 21.9 \\
\hline & 31-40 tahun & 49 & 23.3 \\
\hline & 41-50 tahun & 63 & 30 \\
\hline & 51-60 tahun & 36 & 17.1 \\
\hline & $>61$ tahun & 10 & 4.8 \\
\hline & Total & 210 & 100 \\
\hline \multirow[t]{6}{*}{ Pendidikan } & SMA/SMK & 30 & 14.3 \\
\hline & Diploma & 55 & 26.2 \\
\hline & Sarjana & 83 & 39.5 \\
\hline & Magister & 14 & 6.7 \\
\hline & Lainnya & 28 & 13.3 \\
\hline & Total & 210 & 100 \\
\hline \multirow[t]{6}{*}{ Pekerjaan } & Wiraswasta & 44 & 21 \\
\hline & Swasta & 78 & 37.1 \\
\hline & PNS/BUMN & 54 & 25.7 \\
\hline & Mahasiswa & 29 & 13.8 \\
\hline & Lainnya & 5 & 2.4 \\
\hline & Total & 210 & 100 \\
\hline \multirow[t]{6}{*}{ Lama Berlangganan } & $6-12$ bulan & 53 & 25.2 \\
\hline & 13 - 24 bulan & 50 & 23.8 \\
\hline & 25 - 36 bulan & 53 & 25.2 \\
\hline & 37 - 48 bulan & 35 & 16.7 \\
\hline & $>48$ bulan & 19 & 9 \\
\hline & Total & 210 & 100 \\
\hline \multirow[t]{3}{*}{ Tempat Tinggal } & Surabaya Utara & 42 & 25 \\
\hline & Surabaya Timur & 42 & 25 \\
\hline & Surabaya Selatan & 42 & 25 \\
\hline
\end{tabular}




\begin{tabular}{lll} 
Surabaya Barat & 42 & 25 \\
Surabaya Pusat & 42 & 25 \\
Total & 210 & 100 \\
\hline
\end{tabular}

Sumber: data hasil penelitian (diolah)

Berdasarkan hasil pengumpulan data yang telah dilakukan sebelumnya, diperoleh data mengenai identitas responden untuk melengkapi informasi penelitian. Dimana data kuesioner dibagikan dibagikan di 5 wilayah administratif kota Surabaya yaitu, Surabaya Utara, Surabaya Timur, Surabaya Selatan, Surabaya Barat dan Surabaya Pusat dengan jumlah 42 kuesioner di setiap wilayah. Adapun data responden yang diidentifikasi adalah berdasarkan jenis kelamin, usia, pendidikan terakhir, tempat tinggal, pekerjaan, dan lama berlangganan koran Jawa Pos yang dalam tabel 4.

Berdasarkan jenis kelamin, responden ternyata didominasi oleh pelanggan yang berjenis kelamin wanita yaitu sebanyak 115 orang dengan prosentase $54,8 \%$ dan sisanya adalah responden pria sebanyak 95 orang atau 45,2\%. Sedangkan untuk usia, responden ternyata didominasi oleh pelanggan yang berusia 41-50 tahun yaitu sebanyak 63 orang dengan prosentase $30 \%$. Responden yang berusia $<20$ tahun sebanyak 6 orang atau 2,9\% sedangkan responden yang berusia antara 21-30 tahun sebanyak 46 orang atau 21,9\% kemudian responden yang berusia antara 31-40 tahun sebanyak 49 orang atau 23,3\% selanjutnya responden yang berusia antara 51-60 tahun sebanyak 36 orang atau 17,1\% dan responden yang berusia lebih dari 61 tahun sebanyak 10 orang atau $4,8 \%$.

Selain itu hasil data berdasarkan tingkat pendidikan, responden didominasi oleh pelanggan yang berpendidikan Sarjana yaitu sebanyak 83 orang dengan prosentase 39,5\% diikuti oleh responden yang berpendidikan Diploma sebanyak 55 orang atau 26,2\%. Selain itu untuk responden yang berpendidikan SMA/SMK sebanyak 30 orang atau 14,3\% sedangkan responden yang berpendidikan Magister sebanyak 14 orang atau 6,7\% dan sisanya yang merupakan responden yang berpendidikan selain SMA/SMK, Sarjana, Diploma dan Magister sebanyak 28 orang atau 13,3\%. Untuk data pekerjaan, responden ternyata didominasi oleh pelanggan yang bekerja swasta yaitu sebanyak 78 orang atau $37,1 \%$ selanjutnya responden yang bekerja sebagai PNS/BUMN sebanyak 54 orang atau $25,7 \%$ kemudian responden yang bekerja wiraswasta sebanyak 44 orang atau $21 \%$ sedangkan responden yang bekerja selain wiraswasta, swasta dan PNS/BUMN sebanyak 29 orang atau 13,8\% dan responden yang masih mahasiswa sebanyak 5 orang atau 2,4\%.

Berdasarkan lama berlangganan, responden ternyata didominasi oleh pelanggan yang sudah berlangganan Koran Jawa Pos selama 6-12 bulan dan 25-36 bulan yaitu masing-masing sebanyak 53 orang atau 25,2\% selanjutnya responden yang sudah berlangganan selama 13-24 bulan sebanyak 50 orang atau $23,8 \%$ kemudian responden yang sudah berlangganan selama $37-48$ bulan sebanyak 35 orang atau $16,7 \%$ dan responden yang sudah berlangganan selama lebih dari 48 bulan sebanyak 19 orang atau 9\%. Dan menurut lokasi tempat tinggal, pelanggan bertempat tinggal di surabaya barat, Surabaya pusat, Surabaya selatan, Surabaya timur dan Surabaya utara masing- masing sebanyak 42 orang dengan prosentase $20 \%$.

\section{Hasil Pengujian Validitas Konvergen (Convergent Validity)}

Evaluasi pertama pada model pengukuran adalah validitas konvergen (convergent validity). Untuk melihat hasil pengujian validitas konvergen, dilakukan dengan melihat hasil dari instrumen pengukuran (kuesioner) di output combined loadings dan cross loading. Penilaian validitas konvergen (convergent validity) sendiri didasarkan pada kelayakan model apakah model tersebut valid dan memenuhi convergent validity. 
Selain itu kelayakan sebuah model juga dapat dilihat dari nilai t-statistiknya, dengan syarat $\mathrm{t}$-statistik harus lebih besar dari t-hitung 1,96 pada tingkat signifikasi 0,05 . Untuk selengkapnya, hasil pengujian validitas konvergen dari instrumen pengukuran (kuesioner) pada penelitian ini dapat dilihat pada tabel di bawah ini:

Tabel 2

Hasil Pengujian Validitas Konvergen Kepercayaan Merek

\begin{tabular}{lccc}
\hline \multicolumn{1}{c}{ Butir Pernyataan } & $\begin{array}{c}\text { Original } \\
\text { Sample }(\mathrm{O})\end{array}$ & $\begin{array}{c}\text { Standard Error } \\
(\text { STERR })\end{array}$ & $\begin{array}{c}\text { T Statistics } \\
(|\mathrm{O} / \mathrm{STERR}|)\end{array}$ \\
\hline KM1 <- Kepercayaan & 0.579 & 0.103 & 5.595 \\
KM2 <- Kepercayaan & 0.717 & 0.068 & 10.505 \\
KM3 <- Kepercayaan & 0.422 & 0.165 & 2.560 \\
KM4 <- Kepercayaan & 0.658 & 0.122 & 5.393 \\
KM5 <- Kepercayaan & 0.667 & 0.086 & 7.762 \\
\hline Sumber: & & &
\end{tabular}

Sumber: data hasil penelitian (diolah)

Tabel 3

Hasil Pengujian Validitas Konvergen Citra Merek

\begin{tabular}{lccc}
\hline \multicolumn{1}{c}{ Butir Pernyataan } & $\begin{array}{c}\text { Original } \\
\text { Sample }(\mathrm{O})\end{array}$ & $\begin{array}{c}\text { Standard Error } \\
(\text { STERR })\end{array}$ & $\begin{array}{c}\text { T Statistics } \\
(\mid \mathrm{O} / \mathrm{STERR})\end{array}$ \\
\hline CM1 <- Citra & 0.727 & 0.135 & 5.371 \\
CM2 <- Citra & 0.787 & 0.082 & 9.547 \\
CM3 <- Citra & 0.749 & 0.159 & 4.713 \\
\hline
\end{tabular}

Sumber: data hasil penelitian (diolah)

Tabel 4

Hasil Pengujian Validitas Konvergen Kepuasan Merek

\begin{tabular}{lccc}
\hline \multicolumn{1}{c}{ Butir Pernyataan } & $\begin{array}{c}\text { Original } \\
\text { Sample }(\mathrm{O})\end{array}$ & $\begin{array}{c}\text { Standard Error } \\
(\text { STERR })\end{array}$ & $\begin{array}{c}\text { T Statistics } \\
(\mid \mathrm{O} / \mathrm{STERR})\end{array}$ \\
\hline KPM1 <- Kepuasan & 0.746 & 0.135 & 5.519 \\
KPM2 <- Kepuasan & 0.746 & 0.135 & 5.519 \\
KPM3 <- Kepuasan & 0.443 & 0.121 & 3.655 \\
KPM4 <- Kepuasan & 0.433 & 0.165 & 2.629 \\
KPM5 <- Kepuasan & 0.790 & 0.073 & 10.793 \\
\hline
\end{tabular}

Sumber: data hasil penelitian (diolah)

Tabel 5

Hasil Pengujian Validitas Konvergen Loyalitas Merek

\begin{tabular}{lccc}
\hline \multicolumn{1}{c}{ Butir Pernyataan } & $\begin{array}{c}\text { Original } \\
\text { Sample }(\mathrm{O})\end{array}$ & $\begin{array}{c}\text { Standard Error } \\
(\text { STERR })\end{array}$ & $\begin{array}{c}\text { T Statistics } \\
(\mid \text { O/STERR })\end{array}$ \\
\hline LM1 <- Loyalitas & 0.599 & 0.106 & 5.674 \\
LM2 <- Loyalitas & 0.714 & 0.051 & 13.944 \\
LM3 <- Loyalitas & 0.475 & 0.098 & 4.836 \\
LM4 <- Loyalitas & 0.652 & 0.076 & 8.605 \\
LM5 <- Loyalitas & 0.727 & 0.071 & 10.243 \\
\hline
\end{tabular}

Sumber: data hasil penelitian (diolah) 
Tabel 6

Hasil Pengujian Validitas Konvergen Keinginan Pembelian Ulang

\begin{tabular}{cccc}
\hline Butir Pernyataan & $\begin{array}{c}\text { Original } \\
\text { Sample }(\mathrm{O})\end{array}$ & $\begin{array}{c}\text { Standard Error } \\
(\text { STERR })\end{array}$ & $\begin{array}{c}\text { T Statistics } \\
(|\mathrm{O} / \mathrm{STERR}|)\end{array}$ \\
\hline KPU1 <- Keinginan & 0.793 & 0.052 & 15.334 \\
KPU2 <- Keinginan & 0.792 & 0.052 & 15.177 \\
KPU3 <- Keinginan & 0.652 & 0.091 & 7.166 \\
\hline
\end{tabular}

Sumber: data hasil penelitian (diolah)

Berdasarkan tabel 2 dapat disimpulkan bahwa kelima indikator dari variabel kepercayaan merek dinyatakan valid dan signifikan secara statistik dalam mengukur variabel kepercayaan merek, Hal ini dilihat dari nilai loading $(\lambda)$ dari semua indikatornya yang lebih dari 0,50 dengan T- statistik lebih dari 1,96. Sedangkan berdasarkan pada tabel 3 dapat disimpulkan bahwa ketiga indikator dari variabel citra merek dinyatakan valid dan signifikan secara statistik dalam mengukur variabel citra merek. Hal ini dilihat dari nilai loading $(\lambda)$ dari semua indikatornya yang lebih dari 0,50 dengan T-statistik lebih dari 1,96 . Untuk validitas konvergen (convergent validity) dari tabel 4, dapat disimpulkan bahwa kelima indikator dari variabel kepuasan merek dinyatakan valid dan signifikan secara statistik dalam mengukur variabel kepuasan merek. Hal ini dilihat dari nilai loading $(\lambda)$ dari semua indikatornya yang lebih dari 0,50 dengan T-statistik lebih dari 1,96. Selain itu kesimpulan pengujian validitas konvergen (convergent validity) dari 5, dapat disimpulkan bahwa kelima indikator dari variabel loyalitas merek dinyatakan valid dan signifikan secara statistik dalam mengukur variabel loyalitas merek. Hal ini dilihat dari nilai loading $(\lambda)$ dari semua indikatornya yang lebih dari 0,50 dengan T-statistik lebih dari 1,96.

Selain itu hasil uji yang disajikan pada tabel 6 juga dapat ditarik kesimpulan bahwa ketiga indikator dari variabel keinginan pembelian ulang dinyatakan valid dan signifikan secara statistik dalam mengukur variabel keinginan pembelian ulang. Hal ini dilihat dapat dari nilai loading $(\lambda)$ dari semua indikatornya yang lebih dari 0,50 dengan T-statistik lebih dari 1,96 .

Tabel 7

Uji Discriminant Validity

\begin{tabular}{lccccc}
\hline \multicolumn{1}{c}{ Variabel } & Citra & Keinginan & Kepercayaan & Kepuasan & Loyalitas \\
\hline CM1 & 0.727 & 0.272 & 0.208 & 0.063 & 0.180 \\
\hline CM2 & 0.787 & 0.187 & 0.232 & 0.147 & 0.219 \\
\hline CM3 & 0.749 & 0.162 & 0.195 & 0.177 & 0.164 \\
\hline KM1 & 0.076 & 0.030 & 0.579 & 0.172 & 0.144 \\
\hline KM2 & 0.370 & 0.198 & 0.717 & 0.262 & 0.222 \\
\hline KM3 & 0.062 & 0.026 & 0.422 & 0.039 & 0.104 \\
\hline KM4 & 0.097 & 0.228 & 0.658 & 0.100 & 0.205 \\
\hline KM5 & 0.144 & 0.180 & 0.667 & 0.143 & 0.230 \\
\hline KPM1 & 0.112 & 0.093 & 0.141 & 0.746 & 0.171 \\
\hline KPM2 & 0.112 & 0.093 & 0.141 & 0.746 & 0.171 \\
\hline KPM3 & 0.126 & 0.123 & 0.069 & 0.443 & 0.180 \\
\hline KPM4 & 0.100 & 0.003 & 0.061 & 0.433 & -0.006 \\
\hline KPM5 & 0.127 & 0.233 & 0.269 & 0.790 & 0.425 \\
\hline KPU1 & 0.214 & 0.793 & 0.259 & 0.117 & 0.391 \\
\hline KPU2 & 0.192 & 0.792 & 0.143 & 0.227 & 0.334 \\
\hline KPU3 & 0.218 & 0.652 & 0.099 & 0.165 & 0.231 \\
\hline
\end{tabular}




\begin{tabular}{llllll}
\hline LM1 & 0.094 & 0.280 & 0.103 & 0.420 & 0.599 \\
\hline LM2 & 0.125 & 0.297 & 0.229 & 0.348 & 0.714 \\
\hline LM3 & 0.107 & 0.157 & 0.259 & 0.109 & 0.475 \\
\hline LM4 & 0.214 & 0.227 & 0.103 & 0.147 & 0.652 \\
\hline LM5 & 0.264 & 0.382 & 0.284 & 0.156 & 0.727 \\
\hline CM1 & 0.727 & 0.272 & 0.208 & 0.063 & 0.180 \\
\hline CM2 & 0.787 & 0.187 & 0.232 & 0.147 & 0.219 \\
\hline CM3 & 0.749 & 0.162 & 0.195 & 0.177 & 0.164 \\
\hline KM1 & 0.076 & 0.030 & 0.579 & 0.172 & 0.144 \\
\hline KM2 & 0.370 & 0.198 & 0.717 & 0.262 & 0.222 \\
\hline KM3 & 0.062 & 0.026 & 0.422 & 0.039 & 0.104 \\
\hline KM4 & 0.097 & 0.228 & 0.658 & 0.100 & 0.205 \\
\hline KPM1 & 0.144 & 0.180 & 0.667 & 0.143 & 0.230 \\
\hline KPM2 & 0.112 & 0.093 & 0.141 & 0.746 & 0.171 \\
\hline KPM3 & 0.112 & 0.093 & 0.141 & 0.746 & 0.171 \\
\hline KPM4 & 0.126 & 0.123 & 0.069 & 0.443 & 0.180 \\
\hline KPM5 & 0.100 & 0.003 & 0.061 & 0.433 & -0.006 \\
\hline KPU1 & 0.127 & 0.233 & 0.269 & 0.790 & 0.425 \\
\hline KPU2 & 0.214 & 0.793 & 0.259 & 0.117 & 0.391 \\
\hline KPU3 & 0.192 & 0.792 & 0.143 & 0.227 & 0.334 \\
\hline LM1 & 0.218 & 0.652 & 0.099 & 0.165 & 0.231 \\
\hline LM2 & 0.094 & 0.280 & 0.103 & 0.420 & 0.599 \\
\hline LM3 & 0.125 & 0.297 & 0.229 & 0.348 & 0.714 \\
\hline LM4 & 0.107 & 0.157 & 0.259 & 0.109 & 0.475 \\
\hline LM5 & 0.214 & 0.227 & 0.103 & 0.147 & 0.652 \\
\hline Sumb & 0.264 & 0.382 & 0.284 & 0.156 & 0.727
\end{tabular}

Sumber: data hasil penelitian (diolah)

Berdasarkan nilai cross loading, dapat diketahui bahwa semua indikator yang menyusun masing-masing variabel dalam penelitian ini (nilai yang dicetak tebal) telah memenuhi discriminant validity .

\section{Hasil Pengujian Hipotesis}

Hasil perngujian hipotesis setiap variabel dengan menggunakan software SmartPLS dapat dilihat pada tabel berikut ini.

\section{Pengaruh Kepercayaan Merek Terhadap Loyalitas Merek koran Jawa Pos pada masyarakat Surabaya}

Pengaruh kepercayaan merek terhadap loyalitas merek koran Jawa Pos pada masyarakat Surabaya yang diuji dengan menggunakan SmartPLS dapat dilihat pada tabel 8, hasil analisis data diketahui bahwa nilai koefisien path pada variabel kepercayaan merek sebesar 0,180 dengan nilai t-statistik sebesar 2,124. Karena nilai t- statistik yang dihasilkan lebih dari 1,96 maka H0 ditolak dan $\mathrm{H} 1$ diterima.

Menurut hasil penelitian ini dapat diketahui bahwa bahwa kepercayaan merek memiliki nilai cross loading terbesar untuk variabel yang dibentuknya dan tidak pada variabel yang lain. Dengan demikian semua indikator di setiap variabel dalam penelitian ini telah memenuhi discriminant validity. berpengaruh positif signifikan terhadap loyalitas merek, sehingga hipotesis ini dapat diterima. Hasil penelitian ini sesuai dengan pendapat Penelitian yang dilakukan oleh Nischay K. Upamannyu, dan Garima Mathur (2013) 
menunjukkan bahwa kepercayaan merek (brand trust) memiliki pengaruh positif terhadap loyalitas merek (brand loyalty).

Selain itu penelitian dari Richard Chinomona (2016) ; Abdullah Alhaddad (2015) ; Riyan Hadi Widjaja (2015) ; Kha, Ching Wee, et al. (2012) juga mendukung dan menguatkan hasil penelitian dari Nischay K. Upamannyu, dan Garima Mathur (2013) yang membuktikan bahwa kepercayaan merek (brand trust) berpengaruh positif terhadap loyalitas merek (brand loyalty).

Tabel 8

Uji Pengaruh Kepercayaan Merek Terhadap Loyalitas Merek

\begin{tabular}{lccc}
\hline \multicolumn{1}{c}{ Variabel } & $\begin{array}{c}\text { Original } \\
\text { Sample } \\
(\mathrm{O})\end{array}$ & $\begin{array}{c}\text { Standard Error } \\
(\text { STERR })\end{array}$ & $\begin{array}{c}\text { T-Statistics } \\
(|\mathrm{O} / \mathrm{STERR}|)\end{array}$ \\
\hline $\begin{array}{l}\text { Kepercayaan Merek -> Loyalitas } \\
\text { Merek }\end{array}$ & 0.180 & 0.085 & 2.124 \\
\hline
\end{tabular}

Sumber: data hasil penelitian (diolah)

\section{Pengaruh Citra Merek Terhadap Loyalitas Merek Koran Jawa Pos pada masyarakat Surabaya}

Pengaruh citra merek terhadap loyalitas merek koran Jawa Pos pada masyarakat Surabaya yang diuji dengan menggunakan SmartPLS dapat dilihat pada tabel 9, nilai koefisien path pada variabel citra merek sebesar 0,146 dengan nilai t-statistik sebesar 2,173. Karena nilai t-statistik yang dihasilkan lebih dari 1,96 maka $\mathrm{H} 0$ ditolak dan $\mathrm{H} 1$ diterima.

Dari hasil tersebut maka dapat disimpulkan bahwa citra merek berpengaruh positif signifikan terhadap loyalitas merek, sehingga hipotesis ini dapat diterima.Menurut hasil penelitian ini dapat diketahui bahwa bahwa citra merek berpengaruh positif signifikan terhadap loyalitas merek, sehingga hipotesis ini dapat diterima. Hasil penelitian ini sesuai dengan pendapat penelitian yang dilakukan oleh Nischay K. Upamannyu, dan Garima Mathur (2013) menunjukkan bahwa citra merek (brand image) memiliki pengaruh positif terhadap loyalitas merek (brand loyalty).

Selain itu penelitian dari Salman Habib \& Saira Aslam (2014) dan Abdullah Alhaddad (2015) ) juga mendukung dan menguatkan hasil penelitian dari Nischay K. Upamannyu, dan Garima Mathur (2013) yang membuktikan bahwa citra merek (brand image) berpengaruh positif terhadap loyalitas merek (brand loyalty).

Tabel 9

Uji Pengaruh Citra Merek Terhadap Loyalitas Merek

\begin{tabular}{lccc}
\hline Variabel & $\begin{array}{c}\text { Original } \\
\text { Sample (O) }\end{array}$ & $\begin{array}{c}\text { Standard } \\
\text { Error } \\
\text { (STERR) }\end{array}$ & $\begin{array}{c}\text { T-Statistics } \\
(|\mathrm{O} / \mathrm{STERR}|)\end{array}$ \\
\hline $\begin{array}{l}\text { Kepercayaan Merek -> Loyalitas } \\
\text { Merek }\end{array}$ & 0.146 & 0.067 & 2.173 \\
\hline
\end{tabular}

Sumber: data hasil penelitian (diolah) 
Pengaruh Kepuasan Merek Terhadap Loyalitas Merek koran Jawa Pos pada masyarakat Surabaya

Pengaruh kepuasan merek terhadap loyalitas merek koran Jawa Pos pada masyarakat Surabaya yang diuji dengan menggunakan SmartPLS dapat dilihat pada tabel 10, nilai koefisien path pada variabel kepuasan merek sebesar 0,321 dengan nilai t- statistik sebesar 4,619. Karena nilai t-statistik yang dihasilkan lebih dari 1,96 maka H0 ditolak dan H1 diterima.

Dari hasil tersebut maka dapat disimpulkan bahwa kepuasan merek berpengaruh positif signifikan terhadap loyalitas merek, sehingga hipotesis ini dapat diterima. Hasil penelitian ini sesuai dengan pendapat penelitian yang dilakukan oleh Adi Irianto Marist, Lilik Noor Yuliati, \& Mukhamad Najib (2014) menunjukkan bahwa kepuasan merek (brand satisfaction) memiliki pengaruh positif terhadap loyalitas merek (brand loyalty).

Selain itu penelitian dari Riyan Hadi Widjaja (2015) juga mendukung dan menguatkan hasil penelitian tersebut yang membuktikan bahwa kepuasan merek (brand satisfaction) berpengaruh positif terhadap loyalitas merek (brand loyalty).

Tabel 10

Uji Pengaruh Kepuasan Merek Terhadap Loyalitas Merek

\begin{tabular}{lccc}
\hline \multicolumn{1}{c}{ Variabel } & $\begin{array}{c}\text { Original } \\
\text { Sample }(\mathrm{O})\end{array}$ & $\begin{array}{c}\text { Standard } \\
\text { Error } \\
(\mathrm{STERR})\end{array}$ & $\begin{array}{c}\text { T-Statistics } \\
(\mid \mathrm{O} / \mathrm{STERR})\end{array}$ \\
$\begin{array}{l}\text { Kepuasan Merek -> Loyalitas } \\
\text { Merek }\end{array}$ & 0.321 & 0.070 & 4.619 \\
\hline
\end{tabular}

Sumber: data hasil penelitian (diolah)

\section{Kepuasan Merek Terhadap Kepercayaan Merek koran Jawa Pos pada masyarakat Surabaya}

Pengaruh kepuasan merek terhadap kepercayaan merek koran Jawa Pos pada masyarakat Surabaya yang diuji dengan menggunakan SmartPLS dapat dilihat pada tabel 11, nilai koefisien path pada variabel kepuasan merek sebesar 0,259 dengan nilai t- statistik sebesar 4,208. Karena nilai t-statistik yang dihasilkan lebih dari 1,96 maka H0 ditolak dan H1 diterima.

Dari hasil tersebut maka dapat disimpulkan bahwa kepuasan merek berpengaruh positif signifikan terhadap loyalitas merek, sehingga hipotesis ini dapat diterima. Hasil penelitian ini sesuai dengan pendapat penelitian yang dilakukan oleh Adi Irianto Marist, Lilik Noor Yuliati, \& Mukhamad Najib (2014) menunjukkan bahwa kepuasan merek (brand satisfaction) memiliki pengaruh positif terhadap loyalitas merek (brand loyalty).

Tabel 11

Uji Pengaruh Kepuasan Merek Terhadap Kepercayaan Merek

\begin{tabular}{lccc}
\hline \multicolumn{1}{c}{ Variabel } & $\begin{array}{c}\text { Original } \\
\text { Sample } \\
(\mathrm{O})\end{array}$ & $\begin{array}{c}\text { Standard Error } \\
(\mathrm{STERR})\end{array}$ & $\begin{array}{c}\text { T-Statistics } \\
(|\mathrm{O} / \mathrm{STERR}|)\end{array}$ \\
\hline $\begin{array}{l}\text { Kepuasan Merek -> Kepercayaan } \\
\text { Merek }\end{array}$ & 0.259 & 0.061 & 4.208 \\
\hline ber: data hasil penelitian (diolah) & & &
\end{tabular}




\section{Loyalitas Merek Terhadap Keinginan Pembelian Ulang koran Jawa Pos pada masyarakat Surabaya}

Pengaruh loyalitas merek terhadap keinginan pembelian ulang koran Jawa Pos pada masyarakat Surabaya yang diuji dengan menggunakan SmartPLS dapat dilihat pada tabel 12, nilai koefisien path pada variabel loyalitas merek sebesar 0,438 dengan nilai t-statistik sebesar 7,539. Karena nilai t-statistik yang dihasilkan lebih dari 1,96 maka H0 ditolak dan H1 diterima.

Dari hasil tersebut maka dapat disimpulkan bahwa loyalitas merek berpengaruh positif signifikan terhadap keinginan pembelian ulang, sehingga hipotesis ini dapat diterima. Hasil penelitian ini sesuai dengan pendapat penelitian yang dilakukan oleh Salman Habib dan Saira Aslam (2014) menunjukkan bahwa loyalitas merek (brand loyalty), memiliki pengaruh positif terhadap terhadap keinginan pembelian ulang (repurchase intention), selain itu penelitian dari Ji Feng \& He Yanru (2013) dan Kha, Ching Wee, et al. (2012) juga mendukung dan menguatkan hasil penelitian Salman Habib dan Saira Aslam (2014) yang membuktikan bahwa loyalitas merek (brand loyalty) berpengaruh positif terhadap keinginan pembelian ulang (repurchase intention).

Tabel 12

Uji Pengaruh Loyalitas Merek Terhadap Keinginan Pembelian Ulang

\begin{tabular}{lccc}
\hline \multicolumn{1}{c}{ Variabel } & $\begin{array}{c}\text { Original } \\
\text { Sample (O) }\end{array}$ & $\begin{array}{c}\text { Standard } \\
\text { Error } \\
(\text { STERR })\end{array}$ & $\begin{array}{c}\text { T-Statistics } \\
(|\mathrm{O} / \mathrm{STERR}|)\end{array}$ \\
\hline $\begin{array}{l}\text { Loyalitas Merek -> Keinginan } \\
\text { Pembelian Ulang }\end{array}$ & 0.438 & 0.058 & 7.539 \\
\hline
\end{tabular}

Sumber: data hasil penelitian (diolah)

\section{Simpulan}

Berdasarkan hasil penelitian dan pembahasan yang sudah diuraikan, dapat disimpulkan bahwa bahwa kepercayaan merek, citra merek, dan kepuasan merek berpengaruh positif terhadap loyalitas merek, dan juga loyalitas merek berpengaruh positif terhadap keinginan pembelian ulang.

Dengan hasil penelitian yang diperoleh, disarankan bahwa peneliti selanjutnya diharapkan dapat mengembangkan penelitian ini dengan meneliti faktor lain yang dapat mempengaruhi loyalitas dan keinginan pembelian ulang pelanggan koran. Selain itu, penambahan jumlah sampel juga perlu diperhitungkan mengingat jumlah pelanggan koran Jawa Pos yang berada di kota Surabaya sangatlah besar. Wilayah penelitian juga diharapkan mendapat perhatian lebih sehingga penelitian dapat dilakukan hingga lingkup terkecil yang berada di Kota surabaya seperti lingkup Desa/Kelurahan, dengan tujuan hasil yang didapat nantinya diharapkan bisa mewakili seluruh pelanggan yang berada di wilayah Surabaya. Peneliti selanjutnya juga dapat mempertimbangkan metode lain dalam meneliti loyalitas pelanggan, misalnya melalui wawancara mendalam terhadap pelanggan, sehingga informasi yang diperoleh dapat lebih bervariasi daripada menggunakan instrumen penelitian kuesioner dimana jawabannya sudah tersedia. 


\section{Daftar Referensi}

Alhaddad, A. (2015). A structural model of the relationships between brand image, brand trust and brand loyalty. International Journal of Management Research and Reviews, 5(3), 137.

Alotaibi, S. (2015). How saudis who use the internet see the future of print newspapers in the digital age. Arkansas State University.

Chinomona, R. (2016). Brand communication, brand image and brand trust as antecedents of brand loyalty in Gauteng province of South Africa. African Journal of Economic and Management Studies, 7(1), 124-139.

Frooghi, R., Waseem, S. N., Afshan, S., \& Shah, Z. (2015). Effect of offline parent brand dimension on online trust, satisfaction and loyalty: In Context of Newspaper Industry. Journal of Management Sciences, 2(2), 223-254.

Gigaom. (2014). Everything you need to know about the future of newspapers is in these two charts. Newstex Trade \& Industry Blogs. Chatham: Newstex.

Habib, S., \& Aslam, S. (2014). Influence of Brand Loyalty on Consumer Repurchase Intentions of Coca-Cola. European Journal of Business and Management, 6(14), 168174.

Henriksson, T., 2016. WAN-IFRA. Tersedia: http://www.wanifra.org/articles/2016/06/12/full-highlights-of-world-press-trends-2016-survey [Diakses Tanggal 5 Februari 2017]

Kha, C. W., Goh, E. K., Goh, W., Chin, J. K. P., \& Shim, P. P. (2011). Modelling repurchase intention of Proton automobile using SEM technique, Doctoral dissertation, UTAR.

Kilian, T., Hennigs, N., \& Langner, S. (2012). Do Millennials read books or blogs? Introducing a media usage typology of the internet generation. Journal of Consumer Marketing, 29(2), 114-124.

Kilman, L. 2013. WAN-IFRA. Tersedia: http://www.wan-ifra.org/pressreleases/2013/06/02/world-press- trends-Increasing-audience- engagement-is-futurefor-news-media [Diakses Tanggal 5 Februari 2017]

Kueng, L., \& Picard, R., 2010. Organizational origins of the media industries' troubled response to new technology. In IX World Media Economics and Management Conference, Bogota, Columbia.

Liu, C. T., Guo, Y. M., \& Lee, C. H. (2011). The effects of relationship quality and switching barriers on customer loyalty. International Journal of Information Management, 31(1), 71-79.

Loyalty, B. (2013). Study on the relationships among customer satisfaction, brand loyalty and repurchase intention. Journal of Theoretical and Applied Information Technology, 49(1).

Marist, A. I., Yulianti, L. N., \& Najib, M. (2014). The Role of Event in Building Brand Satisfaction, Trust and Loyalty of Isotonic Drink. International Journal of Marketing Studies, 6(6), 57.

Siswanto, S. (2017). Efek Perkembangan Teknologi Informasi Komunikasi (Ict) Pada Media Cetak Di Era Konvergensi. Prosisko: Jurnal Pengembangan Riset dan Observasi Sistem Komputer, 4(1).

Upamannyu, N. K., \& Mathur, G. (2013, January). Effect of brand trust, brand affect and brand image on customer brand loyalty and consumer brand extension attitude in FMCG sector. In PRIMA (Vol. 3, No. 2, p. 1). Publishing India Group.

Widjaja, R. H., 2015. Studi Explanatory Brand Experience, Brand satisfaction dan Brand Trust Terhadap Brand Loyalty Pada Global Automobile Brand Jenis MPV di Surabaya. Undergraduate thesis, UBAYA 